\title{
24
}

\section{MODERN UTILISATION OF ORGANIC WASTE}

\author{
Dr. Violeta Ivinskiene, \\ Vilnius City Municipality, Lithuania
}

\begin{abstract}
A lot of waste from agriculture, industry, household and food waste is accumulated every year in Lithuania. Waste is polluting environment very intensively. From sanitarian point of view there can appear dangerous sources for people and other biological objects. The main method for utilisation of waste still remains landfilling. So as a huge problem appears operation of landfills, cumulation of leachate and biogas.
\end{abstract}

The last years Vilnius city municipality directly changed the waste managing strategy. As it was estimated, food waste forms about $46,6-56,6 \%$ from total household waste amount. It was decided to turn this source from landfill to composting facilities, organise separate food waste collection from companies and habitants. The system was iniciated in 1997, but it develops very slowly.

A private company "Chitinas" has started its work independently in neighbouring Vilnius city district. Two main unordinal methods were used for destruction of organic waste, both very usual in nature, but still rarely used in practice by farmers. Such methods are called in Lithuania "nontraditional farming". We estimate these methods as modern and perspective for organic waste destruction in big cities. With their help we can get ecologically safe, good natural fertilizers, without seeds and infections, having less nitrates and fosphates. Besides, we get an alternative product - material called "chitin", which could be chemically purified and has a perfect future in chemistry and medicine.

KEYWORDS: Organic waste, food waste, earthworms, fly larves, composting, municipal rules.

\section{SITUATION, TASKS AND ORGANIC WASTE LEGISLATION IN VILNIUS CITY}

The city of Vilnius is situated $300 \mathrm{~km}$ from the Baltic Sea and lies admidst forest covered hills at the confluence of the Neris and Vilnele rivers. It is the capital of Lithuania and the country's largest city with surface of $287 \mathrm{~km}^{2}$ and more than 570000 inhabitants.

Environmental protection and environmental education are recognised as two of the most significant challenges facing Vilnius City Municipality. One of the most important problems in our city is waste management. All these problems are solved by specialists in Environmental Protection Division. 
Till 1992 the only one way of waste utilization was deponing. Then collection of recyclable raw materials was started [1]. Today we have 1600 containers, split in town in micro-districts, where citizens can put glass, paper, plastic and metal waste. Two bulky waste collection sites are operated.

The major part of organic waste from restaurants, canteens and residents is presently disposed on landfill. Deponing of organic waste is not sustainable on a longer term according the regulations of the new EU landfill directive.

The target of Vilnius City is to minimize the quantities of waste and to improve waste management in the town.

First rules for "Arrangement, operation and survey of organic waste composting sites" were approved in Vilnius city municipality in 19971211 by decision of Vilnius City Board No.2019V.

Special rules "For collection and utilisation of food waste" have been worked out in Environmental Protection Division and approved in 19980923 by Vilnius City Council decision No. 244. They are asigned for food processing and other enterprises producing much food waste. Collection of food waste together with other municipal household waste according the rules is forbidden. Food waste must be collected separately and delivered to composting.

Now we are working out the project "FOOD WASTE MANAGEMENT PROGRAMME IN VILNIUS CITY FOR 2000 - 2005. Our task is to create a strategy for special food waste collection and utilisation system in Vilnius. As we see, it can be implemented by two steps: first - collection from enterprises ans second - collection from citizens.

The big source of organic waste would be delivered not to deponing but to processing.

\section{ORGANIC WASTE COMPOSTING IN MUNICIPAL COMPANIES AND INSTITUTES}

\section{Taking part in conferencies and first initiatives}

In 1992 and 1994 as chief ecologist of Vilnius City municipality V. Ivinskiene took part in two conferencies in Kiev and Ivano-Frankovsk (Ukraina), which were discussed composting of organic waste, especially, of sewage water sludge, with help of Californian red earthworms $[2,3]$.

We tried to organize a special subdivision - workshop at Environmental Protection Department of Vilnius city municipaity for this purpose. A draft of feasibility study [4] was prepared by V.Ivinskiene, but a good iniciative failed, because privatization of the lands was started in Lithuania and we could not get a site.

Specialists from Institute of Ecology, Vilnius Water supply company and Geological Office had made many experiments with composting of waste water sludge using various technologies, earthworms as well. As a result of this, requirements for sludge quality had appeared [5]. These requirements show, what kind of sludge could be used in agriculture as fertilizers, for recultivation and renovation of exhausted pits, landfills, etc. [6].

Years have passed. Waste utilisation has got even more actual nowadays. Some private and little state composting companies in county municipalities have been organized. They are composting leaves and branches from Vilnius city parks and streets. 


\section{Composition of Vilnius municipal waste and programme for separate food waste collection}

In 1994 - 1997 composition of Vilnius city household waste has been checked. It was shown, that kitchen waste formed $46,6-56,6 \%$ from total amount, the left part mostly were secondary raw materials. Programme was started in Environmental Protection Division (EPD) for creating separate food waste collection system in Vilnius city. The principal task was to separate organic fraction from the main source of waste, which was deponied, because it caused big problems in landfill - leachate and biogas production. We were planning to implement this programme in three steps:

1. Collection of food waste from municipal objects: schools, children gardens and hospitals was started in 1997, it joined about 100 municipal objects which produce about 700 tones of food waste per year. Transport costs were covered by municipality, from the Nature Protection Fond. In 1999, when the special rules were accepted, municipality stopped paying and the quantities of collected food waste decreased at once. Waste owners simply put it to containers for domestic waste. There was no mechanism to force them keep the rules. So next year we think to renew this experiment as ecological education and pay for collection of food waste from schools and hospitals from the Nature Protection Fond. All food waste was utilized in j/st.c "Chitinas", which was the only one allowed to do such kind of jobs. It has got all permissions from Municipality and Ministry of Environment.

2. Collection of food waste from state, private objects: restaurants, canteens, cafeterias, snack-bars, both all enterprises and shops producing and selling food. We have about 4000 units of such companies in city now. But only 70 units collect food waste separately. As it was mentioned, for this task the special rules were worked out: "The rules for collection and utilisation of food waste" which were distributed to companies.

3. Collection of kitchen organic waste from citizens (a project). A new tax system must be prepared and implemented: different taxes for sorting of different types of wastes: the highest tax ought to be paid for unsorted municipal waste. A special collection and transportation system must be organised. It is complicated, because household waste is removed by seven companies.

Company "Chitinas" 15th of September, 1999, started to run an experiment for three months of separate food collection from habitants in little containers in two communities. The task was to work out a model of collection system. They will find opinion of habitants, get suggestions from companies. The special information leaflet for citizens was prepared, published and delivered. In addition to this, inquest of population opinion was made. We have already got preliminary results.

A new initiation was started this summer - landfill for household waste was reorganised into a separate municipal company and all waste collection companies have got equal possibilities now for work and competition.

So, our tasks in a near future are:

- to work out special municipal rules for citizens;

- to force habitants and companies keep Lithuanian Waste Law (accepted in 199806 16) and municipal legislation rules; for this task we asked hygienists and veterinarians to help us;

- to develop information and education system; 
- to work out a new tax system for collection of different sorts of waste.

\section{UTILISATION OF ORGANIC WASTE IN PRIVATE COMPANY “CHITINAS"}

Joint-stock company "Chitinas" is using three main technologies:

1) usual composting;

2) composting with destruction of organic waste by fly larves;

3 ) composting with destruction of organic waste by earthworms.

They are implementing biological technologies, new and known in Lithuania earlier, on the basis of organic waste collected from Vilnius citizens. After processing three kinds of products are produced: biohumus - organic ecologically safe fertilizers, free from weed seeds, biomass - larves of flies, used as combined fodder for birds and fur-beasts, cultivated at farms; and material - "chitin", separated from biomass.

Some kinds of organic waste such as birds droppings, pig manure, waste from meat enterprises are processed by sinantropic fly larves help. A crude material, received after composting by means of sinantropic fly larves Musca domestica L. is called "chitin" and is mainly composed of this polymere. Chitin at the moment is on the study of investigations. Biohumus is of high contents organic alkaline fertilizer, which corresponds all hygienic requirements and could be used as $\mathrm{P}$ and $\mathrm{N}$ source for vegetables, berries, foot trees, bushes, etc. It is posssible to get $500 \mathrm{~kg}$ of fertilizers, $100 \mathrm{~kg}$ of biomass and $5 \mathrm{~kg}$ of chitin from 1 (one) tone of waste with moisture of $85-90 \%$. All process takes 5 days. The area for production process of $1000 \mathrm{~m}^{2}$ is able to cover processing of 10 tones per day.

Staff of the company together with Lithuanian scientists - biologists and chemisists are improving technologies. 


\section{THE WORKING SCHEME}

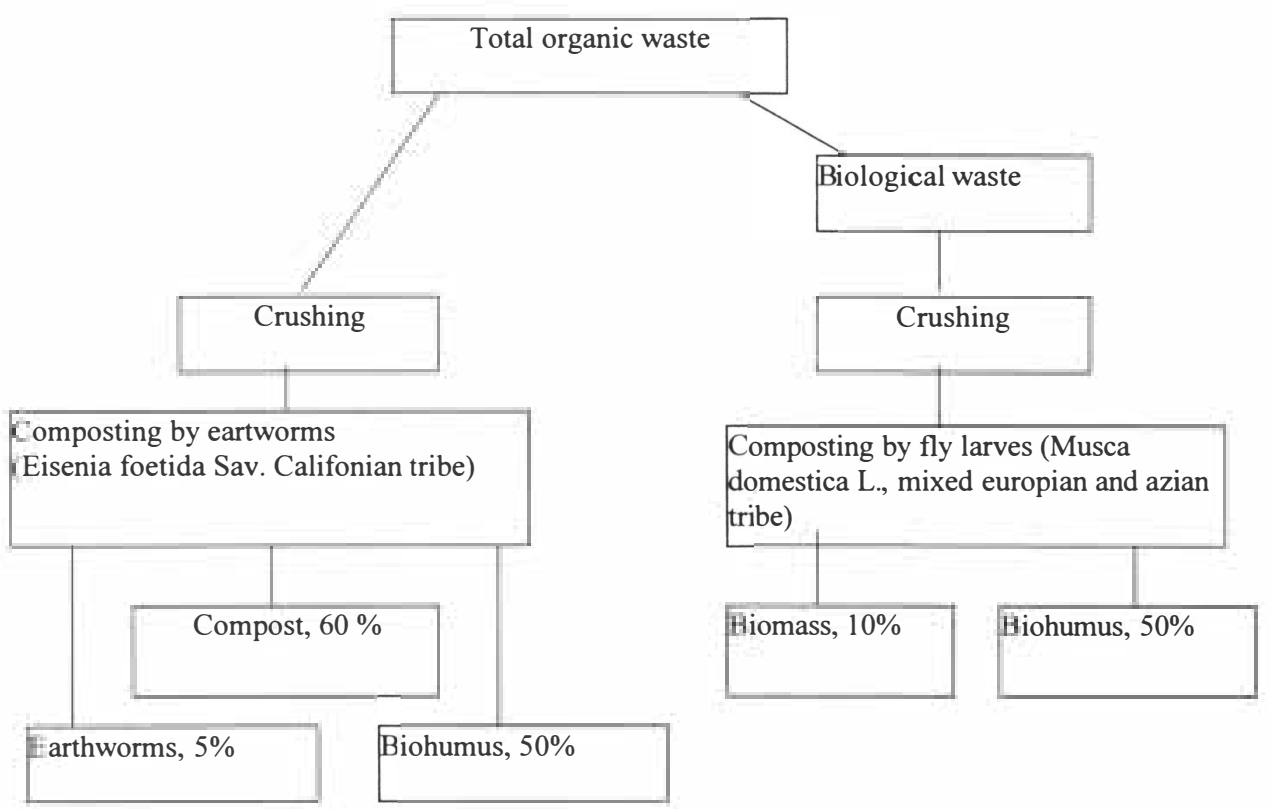

* Part of material seems to be lost because of big moisture in waste.

\section{COMPOSTING METHODS, TRADITIONS AND SCIENTIFICAL WORK IN LITHUANIAN ACADEMY OF SCIENCES}

\section{Traditional composting methods in Lithuania}

Waste conversion by biological methods could be used as one of the most effective metod for utilisation of food, agriculture, some kinds of industrial waste and sewage water sludge. Biological technologies are used successfully for recycling of organic waste in Japan, Slovakia, Korea, China, Russia and others.

Traditionally Lithuanian gardeners and agriculture workers make composts from leaves, little branches, peat, sawdust, straw, spoiled fruits and vegetables, cow, pig, horse and birds manure, ashes, hair, feathers, etc. The first book, known for me, wrote in Lithuanian language, which described and teached gardeners, how one can make a compost, was printed in 1938, [7]. By traditional methods, composting of greenery was made in such a way: various kinds of different organic waste were put into specially located site, one layer covering another. Time by time they were dug over again and poured on by water. There have been used in practice: 
1) Composting in a heap (aerobic).

2) Composting in a fenced in site (aerobic).

3 ) Composting in a refuse pit (process is longer and anaerobic).

Such composting processes are going very long time - about 2 - 3 years.

\section{Nontraditional composting methods}

As non-traditional composting methods, composting with simple red Californian earthworms and house fly larves are used. Narurally these objects destruct organic waste in a very simple way - using it for their nutrition. Several companies, owners and gardeners are using earthworms for composting. Only one Lithuanian company "Chitinas" is using fly larves composting organic waste. These technologies allow to get compost in are very short time - in 2 - 3 months.

\section{Earthworms and flies as the object of organic waste and soil destruction in Lithuanian Institute of Ecology, Academy of Sciences}

The above mentioned objects were studied from fifties till now by ecologists in Lithuanian Academy of Sciences, Institute of Ecology, laboratory of Soil Zoology [8,9,10]. The author of this article, Ivinskiene V. had worked in this laboratory from 1972 till 1992 as soil microbiologist with bacteria's Bacillus thuringiensis, natural insecticides which have a couple of active enzymes - phospholipases, amylases, proteases, chitinases, etc., destructing analogical materials in soil and insect organisms: fats - lipids, lecithins; starch, chitin, various proteins $[11,12]$. Scientists in this laboratory have worked with different objects - pedobionts: flies, earthworms, collembolas, various insects and other invertebrates, which take part in destruction of waste as well. In 1988 P.Kazickas made his $\mathrm{PhD}$ job "Solid waste destruction in landfills by mezofauna," [13], in 1994 S.Pakalniskis made his Ph.D. theses about biology of flies [10]; he is investigating flies from 1979 till 1999.

\section{The Lithuanian Association of lumbricologists}

The Association of lumbricologists (eartworm planters) was organised in Ecological institute in 1990. Most of specialists joined it. The association had about 250 members from various Lithuanian towns and villages. All organisational job was carried by experienced specialist habilitate doctor of sciences O.Atlavinyte. She spent all her life for researching and experimenting with earthworms [8,9]. The leader had died in 1992 and practical work was stoped. After that only local landowners tried to plant earthworms in their own garden-sites $[14,15]$.

\section{CONCLUSIONS}

We have good technologies, much organic waste, but weak organisation of collection system and no mechanism to improve the programme - it is difficult to force enterprises and habitants to keep the rules. Experience and knowledge of other municipalities is needed. We hope to find specialists in Scandinavia countries, who could share their experience with us. We too can share our experience in non-traditional composting methods. 


\section{REFERENCES}

1. Ivinskiene, V., (1995). UAB "Sitis". Buitiniu atlieku surinkimo, rusiavimo ir antrinio panaudojimo Vilniaus mieste ataskaita, (Joint-stock company "Sitis", Report about household waste collection, sorting and second usage in Vilnius city),Vilnius, 50.

2. Ivinskiene, V., (1984). Rolj fosfolipazy i termolabilnovo egzotoksina $\mathbf{v}$ patogennosty bakteriji Bacillus thuringiensis dlia nasekomych i teplokrovnych zyvotnych, (The role of phospholipase and thermolabile exotoxin in pathogenesis of bacteria B.th. for insects and warm-blooded animals". (doctor theses), Leningrad, 156.

3. Kazickas, P.,(1988). Rolj poczvennoj mezofauny $v$ razlozeniji tviordych bytovych otchodov (The role of mezofauna in destruction of solid municipal waste), (doctor theses), Vilnius, 151.

4. Abraityte, A., Rusys, V., (1993). Kalifornijos slieku auginimas (Planting of Californian eartworms), praktiniai patarimai (practical advices), Kaunas, 21.

5. Slieku auginimas. Sudare Cekelienè, V., (1994). (Planting of earthworms, editor Cekeliene, V.), Vilnius, "Vilniaus komprojektas", 35.

6. Spravocznoje posobije po vermikultivirovaniju (Reccommendations for vemiculture), (1992), Associacija "Bioconversija", Ivano-Frankovsk, 72.

7. Biokonversija - perspektivnoje napravlenije agrobiologiczeskoj nauki i praktiki , (1992), (Bioconversion - a perspective direction of agrobiological science and practice), IvanoFrankovsk, 33.

8. Technine - ekonomine kompostavimo aiksteliu parinkimo ir irengimo Vilniaus mieste analize, pasiulymai projektui, (1994), (Technical -economical analysis for location and arrangement of composting sites in Vilnius city, feasibility study, Environmental protection department of Vilnius city municipality, a draft), 60e

9. Vilniaus miesto nuoteku dumblo panaudojimas sunaikintoms zemems rekultivuoti ir tresti, (1997), (Utilisation of Vilnius city sewage sludge for recultivation and fertilisation of destroyed soils) red. Eitminaviciute, I., Janeliauskiene, D., Kisielis, V., Vilnius, 317.

10. Eitminaviciute, I., Bagdanaviciene, Z., (1944). Lietuvos miestu nutekamuju vandenu dumblas ir jo panaudojimas; normatyvai, (Utilisation of Lithuanian sewage water sludge, normatives), Ekologijos institutas; (Institute of Ecology), Vilnius, adopted by Lithuanian EPD and LR Health protection ministry, 19930719 oder No. 50/312, 3-29.

11. Kriksciūnas, J., Strazdas, A., (1938). Darzoviu ir sakniavaisiu auginimas (Planting of vegetables and roots), Kaunas, 67.

12. Atlavinyte, O., (1975). Ekologija dozdevych czervej i ich vlijanie na plodorodije poczvy v Litovskoj SSR, (Ecology of earthworms and their influence on soil fertility in Lithuanian SSR), Vilnius, 202.

13. Atlavinyte, O., Kazickas, P., (1982). Vlijanije dozdevych czervej vida Eisenia foetida Sav. na razlozenyje organiczeskich ostatkov, (Problemy i metody biologiczeskoj destrukciji organiczeskich vesczestv $\mathrm{v}$ poczve estestvennych biocenozov i agrocenozov), (The influence of earthworms species Eisenia foetida Sav. upon destruction of organic waste, in book "Problems and methods of biological destruction of organic soil materials in natural biocenoses and agrocenoses), Lvov, $26-27$.

14. Pakalniskis, S., (1994). Lietuvos minuojantieji dvisparniai vabzdziai, (Lithuanian mining dipterous insects), (doctor theses), Vilnius, 106.

15. Ivinskiene, V., Bulbulshojev, T., (1990). Vydelenije novych stammov Bacillus thuringiensis v vysokogornych rajonach zapadnovo Pamyra, (Purification of the new stammes of Bac.th. in the mountain districts of West Pamyr), theses, Moskva, 26-27. 